\title{
Optical Properties of the Urban Aerosol Particles Obtained from Ground Based Measurements and Satellite-Based Modelling Studies
}

\author{
Genrik Mordas, Nina Prokopciuk, Steigvilè Byčenkienė, \\ Jelena Andriejauskiené, and Vidmantas Ulevicius \\ SRI Center for Physical Sciences and Technology, Savanoriu Avenue 231, LT-02300 Vilnius, Lithuania \\ Correspondence should be addressed to Steigvilè Byčenkienė; steigvile.bycenkiene@ftmc.lt
}

Received 29 January 2015; Revised 29 April 2015; Accepted 2 May 2015

Academic Editor: Yang Liu

Copyright (C) 2015 Genrik Mordas et al. This is an open access article distributed under the Creative Commons Attribution License, which permits unrestricted use, distribution, and reproduction in any medium, provided the original work is properly cited.

Applications of satellite remote sensing data combined with ground measurements and model simulation were applied to study aerosol optical properties as well as aerosol long-range transport under the impact of large scale circulation in the urban environment in Lithuania (Vilnius). Measurements included the light scattering coefficients at 3 wavelengths (450, 550, and 700 nm) measured with an integrating nephelometer and aerosol particle size distribution $(0.5-12 \mu \mathrm{m})$ and number concentration $\left(D_{\mathrm{pa}}>\right.$ $0.5 \mu \mathrm{m})$ registered by aerodynamic particle sizer. Particle number concentration and mean light scattering coefficient varied from relatively low values of $6.0 \mathrm{~cm}^{-3}$ and $12.8 \mathrm{Mm}^{-1}$ associated with air masses passed over Atlantic Ocean to relatively high value of $119 \mathrm{~cm}^{-3}$ and $276 \mathrm{Mm}^{-1}$ associated with South-Western air masses. Analysis shows such increase in the aerosol light scattering coefficient $\left(276 \mathrm{Mm}^{-1}\right)$ during the 3rd of July 2012 was attributed to a major Sahara dust storm. Aerosol size distribution with pronounced coarse particles dominance was attributed to the presence of dust particles, while resuspended dust within the urban environment was not observed.

\section{Introduction}

The atmospheric aerosol particles have significant direct and indirect effects on air quality, climate, and human health [1]. The impacts of particles depend on their physical and chemical properties [2-4]. Thus, the characterization of the aerosol properties is crucial to understand many important processes in the atmosphere and to examine the energy balance of the Earth. The coming solar radiation is modified when it passes through the atmosphere by two main processes: the light scattering and the light absorption. The attenuation of the light by these processes has important climatic consequences $[5,6]$. Aerosol particles both absorb and scatter the light, with the efficiency of the processes being highly dependent on their size and shape, chemical composition, morphology, and the wavelength of the incident radiation [7-9]. The maximum in scattering efficiency is found for aerosol particles in a range from 0.1 to $1 \mu \mathrm{m}$ [7]. The integrating nephelometer is widely used for the measurement of the light scattering coefficient
$[8,9]$ in the marine boundary layer $[10,11]$ and in the urban environment [12].

Most studies have examined parameters, which depend on the quantity of aerosol, such as AOD, and parameters depend on the aerosol characteristics, such as the scattering Ångström exponent [13, 14]. Aerosol optical properties at regional scale have been studied since 1990s with model simulations [15-17] and satellite-based retrievals [18-20]. Satellite data from MODIS have been used to retrieve the AOD measurements of dust storm events [21, 22] as aerosol particles may be transported over long distances. Long-range transport of Saharan dust to the Northern parts of Europe was observed [23]. The climate and aerosol communities are increasingly relying on satellite-derived aerosol data for research as well as for monitoring [24]. Aerosol products from NASA's Moderate Imaging Spectrometer (MODIS) [25] sensor were utilized in the latest IPCC (AR5) assessment of climate (IPCC, 2014) [26]. Satellite-derived aerosol products, including those from MODIS, have been used for air quality 
monitoring on both regional and local scales [27, 28]. One important and common aerosol parameter retrieved from satellite sensors is the aerosol optical depth (AOD). Generally, a higher AOD value indicates higher aerosol loading and therefore low visibility. It should be noted that the AOD values represent vertical column properties, whereas the $\mathrm{PM}_{2.5}$ or $\mathrm{PM}_{10}$ data are the "surface" data. The AOD data do not always have good correlation with the PM data measured at the ground station. AOD is not an ideal indicator of the exact average size of particles as it depends on the absorption property of aerosols [29]. The satellite technique proved to be a suitable tool for the study of aerosol optical properties and long-range transport. Main advantage of satellite is the real time observation, which can be used to identify the origin and the path of air mass. This technique has its uncertainty limitations, but, in combination with surface based measurements such as nephelometer, important information about aerosol origin, type, and distribution can be derived [30]. This study is focused on detailed analysis of an intensive case of air pollution in Lithuania.

The current study describes the results combining data obtained by a nephelometer, aerosol particle sizer, and satellite-based datasets. Air masses from North and Eastern Europe, from the Atlantic Ocean, and from South-Western part of Europe have been advected to the monitoring site during the study period in accordance with back-trajectories and satellite images. It is shown in the study that only the integration of data from different instruments gives the possibility to properly characterize the contribution of different aerosol types (sizes) during long-range transport. A description of the experiment methodology is given in Section 2. Results are analyzed and discussed in Section 3.

\section{Instrumentation and Methods}

2.1. Sampling Location. Ground based measurements of the aerosol physical and optical properties were performed during July 2012 in Vilnius (Lithuania) $\left(54^{\circ} 38^{\prime} 36^{\prime \prime} \mathrm{N}, 25^{\circ} 10^{\prime} 58^{\prime \prime} \mathrm{E}\right)$ at the top floor of the academic building of the Center for Physical Sciences and Technology campus. The inlet of sampling system was placed on the top floor about $12 \mathrm{~m}$ above the ground level. The location can be described as an urban background.

2.2. Nephelometer. The light scattering coefficient was measured at three wavelengths, $\lambda=450,550$, and $700 \mathrm{~nm}$, using an integrating nephelometer TSI model 3563. The nephelometer geometry restricts the sensing of the total aerosol scattering to angles between $7^{\circ}$ and $170^{\circ}$. The nephelometer was operated at a $30 \mathrm{~L} / \mathrm{min}$ flow rate. The measured values of the aerosol scattering coefficients $\left(\sigma_{\mathrm{sp}}\right)$ are recorded every $5 \mathrm{~min}$ and an automatic calibration is performed every $60 \mathrm{~min}$ for setting the instrument background level. The instrument background determines the detection limit of the light scattering measurement and it has been assessed as the standard deviation (SD) of the zero baseline measurements. The investigation of the nephelometer performance characteristics is presented by [31, 32]. On the front of the nephelometer was installed a $15 \mathrm{~cm}$ long stainless steel tube with a diameter of
$30 \mathrm{~mm}$ in 60 degrees from horizontal and a connected vertical $\sim 5 \mathrm{~m}$ length stainless steel tube with a diameter of $30 \mathrm{~mm}$ with open conductive inlet protection from precipitation. The sampled aerosol losses and the instrument cut-size were estimated by empirical relationship $[33,34]$. The resulting calculated cut-size was $10 \mu \mathrm{m}$ at a typical measured wind speed of $3 \mathrm{~m} / \mathrm{s}$.

The particle scattering coefficient $\sigma_{\text {sp }}$ decreases with wavelength and can be described as

$$
\sigma_{\mathrm{sp}}=B \lambda^{-\alpha}
$$

where $B$ is a constant known as the turbidity coefficient, $\lambda$ is wavelength of light, and $\alpha$ is an Ångström exponent coefficient. Using the measured light scattering coefficient data at 450 and $700 \mathrm{~nm}$ wavelength pair, the corresponding values of the Ångström exponent can be calculated by the following equation:

$$
\alpha=\frac{-\ln \left[\sigma_{\mathrm{sp}}{ }^{700} / \sigma_{\mathrm{sp}}{ }^{450}\right]}{\ln (700 / 450)},
$$

where $\sigma_{\mathrm{sp}}{ }^{700}$ is the measured light scattering coefficient at the wavelength of $700 \mathrm{~nm}$ and $\sigma_{\mathrm{sp}}{ }^{450}$ is the measured light scattering coefficient at the wavelength of $450 \mathrm{~nm}$. The wavelength pair of 450 and $700 \mathrm{~nm}$ gives more accurate determination of the Angström exponent because of the larger difference in the values of the measured light scattering coefficients. The calculated Ångström exponent describes the domination of the fine or coarse particles on the measured integrated light scattering coefficient. So, if there are high values of the Angström exponent, then the fine particles of $0.1-1.0 \mu \mathrm{m}$ had larger domination on the value of the measured date. Low $\alpha$ values (close to zero) indicate domination by coarse particles of 1.0-10 $\mu \mathrm{m}$ [35]. The determination of the Ångström exponent allows characterizing and selecting different sources of the aerosol particles. The light scattering coefficient is dependent on the aerosol particle number concentration and the particle size. However, if the particle size is smaller than the used wavelength, the efficiency of the light scattering is very low. Thus, the measured integrated light scattering coefficient is determined only by the optically detectable particles.

2.3. Aerodynamic Particle Sizer. The aerosol particle number concentration and the particle size distribution were investigated with the aerodynamic particle sizer of TSI model 3321. The APS measures the aerodynamic diameter of individual particles (from 0.5 to $20 \mu \mathrm{m}$ ) based on the particle velocities immediately downstream of a flow accelerating nozzle. The instrument was operated using the high total flow rate of $5 \mathrm{~L} / \mathrm{min}$ (an aerosol flow is $1 \mathrm{~L} / \mathrm{min}$ and a clean sheath flow is $4 \mathrm{~L} / \mathrm{min}$ ). The aerosol particle size distribution and the particle number concentration $\left(D_{\mathrm{pa}}>0.5 \mu \mathrm{m}\right)$ were determined in real time averaging the measured data every 5 minutes. The APS used individual sampling line. The sampling aerosol flow passed through PM10 impactor and a vertical $\sim 2.5 \mathrm{~m}$ long stainless steel sampling tube $(6 \mathrm{~mm}$ i.d.) before reaching the instruments. Particle losses in the line were estimated to be lower than $2 \%$. 
2.4. Air Mass Backward Trajectories Analysis. The air mass trajectories were calculated using the Hybrid Single-Particle Lagrangian Integrated Trajectories model Version 4 (HYSPLIT4) [36]. 96-h backward trajectories at 500, 1500, and $2500 \mathrm{~m}$ a.g.l. were calculated to identify the origin of the air masses. The analysis of air masses allowed determining the most important sectors, which have an effect on the air quality in Lithuania. The dispersion model used meteorological data fields that were obtained from dataset archives.

2.5. CALIPSO, NAAPS, and MODIS Retrievals. The Navy Aerosol Analysis and Prediction System (NAAPS) has been used to explore the spatial distribution of the AOD. NAAPS was developed at the Naval Research Laboratory in Monterey, USA, based on the Danish Eulerian Hemispheric Model (DENM). The offline model NAAPS utilizes the meteorological analysis and forecast field from 0.5-degree Navy's Operational Global Analysis and Prediction System (NOGAPS) $[37,38]$. The model calculation result is an optical depth at a wavelength of $550 \mathrm{~nm}$ for three components (sulphate, dust, and smoke). The dust distribution was simulated for aerosol particles of $1.0 \mu \mathrm{m}$ in the diameter having a refractive index of $1.55+0.001 \mathrm{i}$. As a result, the dust distribution is illustrated by a common modeling parameter, an aerosol optical depth. Additionally, the AOD was determined by MODIS Terra and Aqua satellites using the calculation algorithm over land surface [39-42]. The aerosol optical depth is computed at 470, 550, and $660 \mathrm{~nm}$ wavelengths [43, 44]. However, the wavelength of $550 \mathrm{~nm}$ is more useful for our investigations because the same wavelength is used by the nephelometer and the NAAPS model. Dust plume layers were evaluated by the Cloud-Aerosol Lidar and Infrared Pathfinder Satellite Observation (CALIPSO) Level-2 aerosol products (Version3.01) such as aerosol layer identification by total attenuated backscatter. Vertical feature masks were used to determine the heights of structures and to distinguish aerosols from cloud; the $532 \mathrm{~nm}$ total attenuated backscatter and depolarization ratio were checked.

\section{Results and Discussion}

3.1. Ground Based Measurements. The light scattering coefficients at 450, 550, and $700 \mathrm{~nm}$ and Ångström exponent are illustrated in Figure 1. Figure 1(a) shows that the $1 \mathrm{~h}$ averaged scattering coefficient values varied in the range from 4.0 to $369.0 \mathrm{Mm}^{-1}$. There is a similar trend in the variations of the light scattering coefficients at different wavelength. The average of the light scattering coefficient at 450, 550, and $700 \mathrm{~nm}$ was found to be 30.5 ( $\mathrm{SD}=23.8), 20.2(\mathrm{SD}=16.7)$, and 12.8 $(\mathrm{SD}=11.3) \mathrm{Mm}^{-1}$, respectively. The highest values for $\sigma_{\text {sp }}{ }^{450}=369$ and $\sigma_{\text {sp }}{ }^{700}=195 \mathrm{Mm}^{-1}$ were observed mostly at the beginning of the month. High positive correlations of 0.99 and 0.98 were found between 450 and $550 \mathrm{~nm}$ and 450 and $700 \mathrm{~nm}$ wavelengths. In order to use ground based measurements, data of the light scattering coefficient at $550 \mathrm{~nm}$ were selected investigating the trends of the particle optical properties and comparing the ground based measurements with the satellite determined AOD. Meanwhile, the light scattering coefficients at wavelength of 450 and $700 \mathrm{~nm}$ were

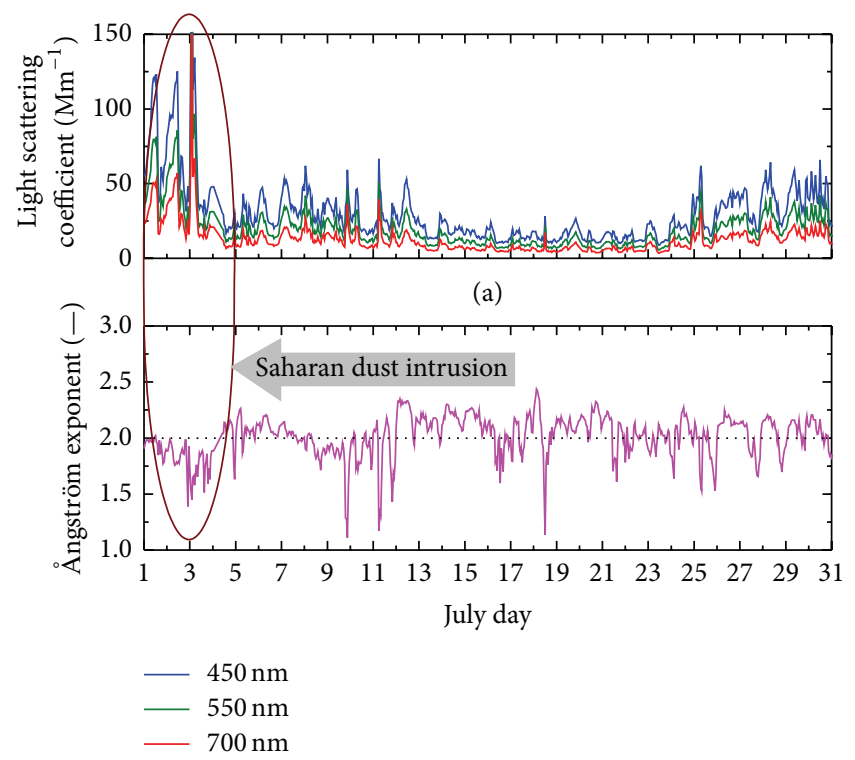

(b)

FIGURE 1: (a) The light scattering coefficient for the wavelength of 450, 550, and $700 \mathrm{~nm}$ during July 2012. (b) The calculated Ångström exponent for 450 and $700 \mathrm{~nm}$ wavelength pair filtered with a 2-point moving average filter. The oval highlighted area shows Saharan dust intrusion.

useful characterizing aerosol particle sources by Ångström exponent values.

The Ångström exponent (Figure 1(b)) analysis allowed us to determine the domination of the aerosol fine and coarse modes using scattering coefficient data [45]. Figure 1(b) shows that the typical Ångström exponent values were ranged from 1.1 to 2.4 with the average of $\sim 2.0$ ( $\mathrm{SD}=0.2$ ). The positive fluctuation of the Ångström exponent up to averaged value was about $15 \%$ and presented the domination of the coarse particles. It is seen that the fluctuations of Ångström exponent values below average value were more pronounced ( $45 \%)$ compared with the typical Ångström exponent mean value. The statistical analysis of the frequency distribution of Ångström exponent showed a peak of 2.0 that is typical for places affected by the urban or continental pollution $[12,46]$. It is also shown that the aerosol particle optical properties during the 3rd of July could be strongly affected by the long-range transport (discussion in Section 3.3). It should be noted that extreme light scattering values at $700 \mathrm{~nm}$ occurred influencing aerosol number concentration as well (Figure 2). Consequently, the light scattering coefficients in conjunction with Ångström exponent and number concentration analysis can be helpful in determining the influence of the far located pollution sources on the regional air quality. The variation of the total particle number concentration and light scattering coefficient is presented in Figure 2.

Figure 2 shows that the typical number concentration varies between several particles and $40 \mathrm{~cm}^{-3}$. The statistical examination showed that the mean aerosol number concentration was found to be $12 \mathrm{~cm}^{-3}\left(\mathrm{SD}=9 \mathrm{~cm}^{-3}\right)$ during the study period. However, several high peaks of the particle 


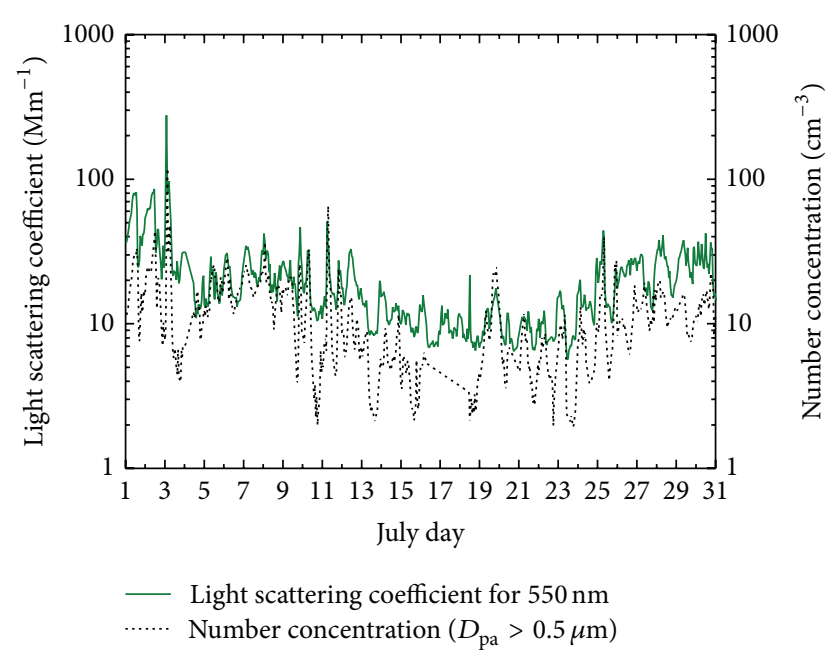

FIGURE 2: The variations of the light scattering coefficient (at $550 \mathrm{~nm})$ and the particle number concentration $\left(D_{\mathrm{pa}}>0.5 \mu \mathrm{m}\right)$.

number concentration were observed on 1 st $\left(33 \mathrm{~cm}^{-3}\right)$, 2nd $\left(43 \mathrm{~cm}^{-3}\right)$, 3rd $\left(118 \mathrm{~cm}^{-3}\right)$, 11th $\left(65 \mathrm{~cm}^{-3}\right)$, 19th $\left(24 \mathrm{~cm}^{-3}\right)$, and 25 th $\left(39 \mathrm{~cm}^{-3}\right)$ of July. Therefore, below we focused our study on relationship between the particle number concentration and the light scattering coefficient (Figure 2). Statistical analysis of data showed a positive correlation $\left(R^{2}=0.82\right)$ between light scattering coefficient and particle number concentration. The relationship between the light scattering coefficient (at $550 \mathrm{~nm}$ ) and the particle number concentration $\left(D_{\mathrm{pa}}>0.5 \mu \mathrm{m}\right)$ is shown in Figure 3 as a solid line with top and bottom dot lines, which characterize the critical ranges of particle refractive indexes. A solid line with top and bottom dot lines characterizes the critical ranges of dispersion. The middle line, the so-called "bisector" (Figure 3), describes a linear dependence of the light scattering coefficient on the particle number concentration. Presumably, the urban aerosol is more heterogeneous according to the particle chemical composition. As a result, the refractive index varies in a wide range. Two dominating types of the urban aerosol particles were determined (Figure 3). Most important parameters for scattering, holding the refractive index constant, allowed exploring observed changes in scattering/absorption due to changes in particle size. The measured optical properties and the relationship between the light scattering coefficient (at $550 \mathrm{~nm}$ ) and the particle number concentration $\left(D_{\mathrm{pa}}>0.5 \mu \mathrm{m}\right)$ in different air masses (Figure 3) arriving from different areas showed that the changes in particle size explain most of the variability in scattering. It is shown that increasing particle number concentration in the "low scattering sector" has a little effect on the value of the light scattering coefficient. The angle between two bisectors characterizes the homogeneity of the aerosol optical properties. Thus, the aerosol optical properties can be characterized by three empirical parameters: (1) the angle $\alpha_{H}$ between the "bisector" of "high scattering sector" and $x$-axis, (2) the angle $\alpha_{L}$ between the "bisector" of "low scattering sector" and $x$-axis, and (3) the angle $\beta$ between two

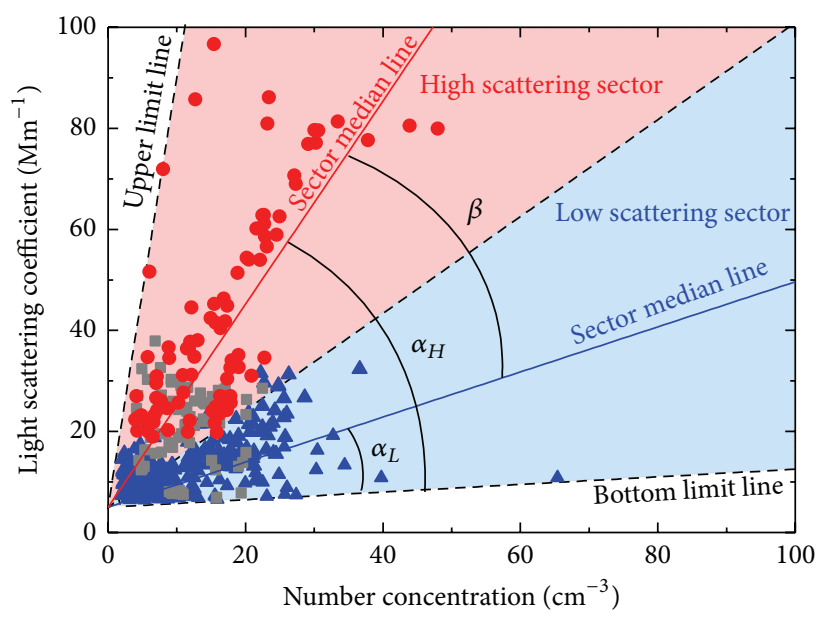

FIGURE 3: The relationship between the light scattering coefficient (at $550 \mathrm{~nm})$ and the particle number concentration $\left(D_{\mathrm{pa}}>0.5 \mu \mathrm{m}\right)$ in different air masses arriving from Sahara storm area (red), Atlantic Ocean (blue), and continent (grey).

bisectors. We suggest that the data dispersion is dependent mainly on particle refractive indexes. So the homogeneous particles have a single refractive index. More detailed analysis of both sectors allowed concluding that the particles from "high scattering sector" were observed during the air mass transport from the Mediterranean Sea basin and the Sahara desert (Section 3.3).

The air masses arriving from Atlantic Ocean and continent sector are presented in "low scattering sector."

Contrary to the urban environment and for products of the burning processes, the Angström exponent of the desert aerosol has very low values $(\alpha<1)$ [47]. For example, during the Saharan dust intrusion into Europe in OctoberNovember 2001, the Ångström exponent decreased up to 0.68 , when its variation varied from 1.20 to 1.45 before and after the dust event in Kishinev [47]. The Ångström exponents lower than 0.5 during the Saharan dust events were also observed at the Global Atmospheric Watch (GAW) laboratory at the high alpine research station Jungfraujoch ( $3580 \mathrm{~m}$ above sea level) in Switzerland [48]. It should be noted that Ångström values of $<0.5$ also can indicate the presence of sea salt particles in the clean marine environment [49]. Close to the dust source region (Sahara desert), the aerosol optical properties show mostly pure dust particles. However, after a long-range transport of the air masses, a vapour condensation, particle coagulation, sedimentation, and mixing with the other aerosol types could modify aerosol physical, chemical, and, as a result, optical properties [50] (Figure 3) (grey square dots). It is known that the mixing of the Sahara dust particles with anthropogenic aerosol has the largest effect on the aerosol properties [51, 52]. So it can be pointed out that the influence of the anthropogenic particles on the direct radiative forcing needs to take into account analyzing Sahara desert dust intrusions over the Mediterranean basin and continental Europe $[53,54]$. 
TABLE 1: The comparison of the aerosol optical depth, the light scattering coefficient (at $550 \mathrm{~nm}$ ), and the particle number concentration $\left(D_{\mathrm{pa}}>0.5 \mu \mathrm{m}\right)$ averaged daily.

\begin{tabular}{lccc}
\hline July 2012 & $\begin{array}{c}\text { AOD, } \\
-\end{array}$ & $\begin{array}{c}\text { Light scat. coef., } \\
\mathrm{Mm}^{-1}\end{array}$ & $\begin{array}{c}\text { Number conc., } \\
\mathrm{cm}^{-3}\end{array}$ \\
\hline 01 & 0.32 & 50.3 & 19 \\
03 & 0.35 & 50.1 & 19 \\
07 & 0.10 & 25.9 & 20 \\
09 & 0.30 & 23.0 & 15 \\
11 & 0.12 & 19.7 & 15 \\
24 & 0.02 & 14.9 & 7 \\
25 & 0.12 & 20.2 & 15 \\
26 & 0.02 & 24.0 & 11 \\
28 & 0.20 & 26.3 & 14 \\
29 & 0.22 & 28.0 & 11 \\
30 & 0.26 & 27.9 & 15 \\
\hline
\end{tabular}

\subsection{Satellite Data}

3.2.1. Aerosol Optical Depth. The cloudy atmosphere prevented the continuous satellite measurements of the AOD over Vilnius during study period and the satellite AOD data consist of eleven events only (Table 1).

The table shows that AOD varied in a wide range from 0.02 to 0.35 compared with the typical AOD of 0.20 (Table 1 , Figure 1). The satellite AOD measurements were compared with the ground based measurements of the light scattering coefficient and the particle number concentration $\left(D_{\mathrm{pa}}>\right.$ $0.5 \mu \mathrm{m})$. Moderate positive correlation $(R=0.7, P=0.01)$ was found between AOD and the light scattering coefficient as well as with particle number concentration $(R=0.6$, $P=0.01)$. So the satellite measurements of the AOD are more useful for the global atmosphere aerosol distribution monitoring and the sun radiation absorption modelling. However, the characterization of optical properties of the local aerosol particles cannot be done accurately based only on the AOD satellite measurements over Lithuania. Thus, detailed characterization of the aerosol optical properties can be obtained based on the ground based measurements of the light scattering coefficient and the particle number concentration and size distribution.

3.3. Air Mass Clustering and Sahara Dust Event. By dividing the source regions into clusters (sectors), it was possible to classify and understand the relative influence of each sector in the typical characteristics of the air masses arriving over the measurement site (Vilnius) and to evaluate the dependence of these optical and physical aerosol particle properties on the dominant air mass type. To identify the origin of air masses arriving above study area, the backward trajectories were classified into five main clusters. Investigating the clusters revealed five sectors: one cluster was in the Northern direction, "N," and two clusters were in the Western and South-Western direction, "W" and "SW" One cluster was in the Eastern direction, "E." Sector "N" defines continental polar air masses and includes Scandinavian region. "W" and "SW" air masses reached Preila area from Atlantic Ocean but "W" passed dominantly through the industrial European regions (Great Britain, France, Germany, Czech Republic, and Poland), while "SW" originated over North Africa (Egypt and Morocco) and the Mediterranean Sea basin. Days under the influence of different air masses and Sahara dust outbreaks were identified by means of backward trajectories and satellite map analysis, and then aerosol number concentration and Ångström exponent levels were evaluated for these days. It was determined that cold air masses with the marine aerosol particles from the Atlantic Ocean passed over the Western region. On the contrary, sector "SW" is characterized by continental air masses with a significant load of dust due to the Saharan desert storm causing the advection of dust and aerosol particles into highaltitude layers from where they were transported to higher latitudes and study area. The air masses coming from this sector were expected to have low Ångström exponent values and a size distribution with a coarse mode dominating the accumulation mode. The industrial European region affected air masses and, as a result, aerosol particles properties; for example, East sector, "E," combined the air masses from the continent (Ukraine, Belarus, and Russia). The "N" and "W" clusters' air masses were influenced by cleanest conditions (especially on 20-25 July (not shown)), which were associated with the lowest light scattering coefficients and the lowest particle number concentrations $\left(D_{\mathrm{pa}}>0.5 \mu \mathrm{m}\right)$. The Western and Northern directions' clusters represented $48 \%$ of the total trajectories. The South-Western cluster represented $29 \%$ and the Eastern cluster 23\%. To illustrate the difference in the air mass origin, the events of each type were selected for case studies (Figures 4-6). The light scattering coefficient of $28 \mathrm{Mm}^{-1}$ for $550 \mathrm{~nm}$ and the particle number concentration of $20 \mathrm{~cm}^{-3}$ were registered on 29 July (Figure 4).

Figures 4(c) and 4(d) indicate that the Angström exponent is quite sensitive to the aerodynamic diameter of size distributions that are consistent with fine mode aerosols; that is, an increase in the Ångström exponent (9 p.m.) up to 2.2 showed increase in particles smaller than $\sim 0.4 \mu \mathrm{m}$ (9 a.m.).

The effect of the local pollution sources can be seen on 14 July, despite the fact that the air masses from industrialized areas (sector "W") of Europe were observed (Figure 5(a)). The aerosol number concentration increased during the morning traffic peak (5-7 a.m.) hour and again in the evening (710 p.m.). After the morning traffic peak hour, the number concentration rapidly decreased. This phenomenon can be explained by mixing within the developing boundary layer. Low mean light scattering coefficient of $12.8 \mathrm{Mm}^{-1}$ and mean particle number concentration of $6.0 \mathrm{~cm}^{-3}$ were found (Figure 5(b)).

The calculated Ångström exponent varied from 2.0 to 2.3 (Figure 5(c)) with the mean value of 2.2. However, the high Ångström exponent values associated with coarse mode aerosols could significantly reduce the particle number concentration. It is also evident in Figure 5(d) that a decrease in the Ångström exponent values (3 a.m.) corresponds to an increase in number concentration in the fine mode aerodynamic diameter and coarse particles as well, highlighting 


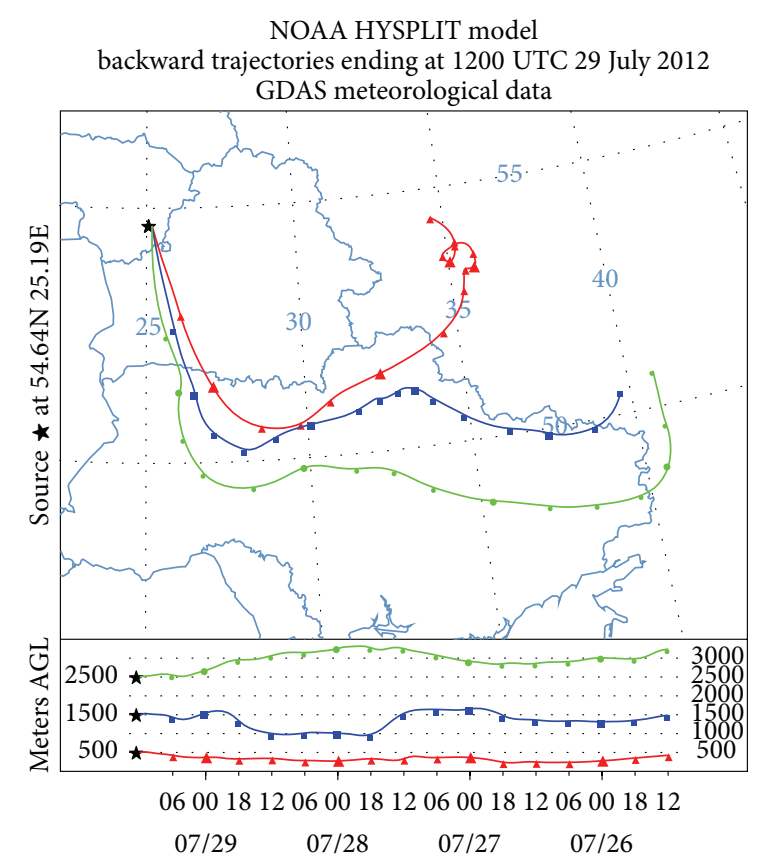

(a)

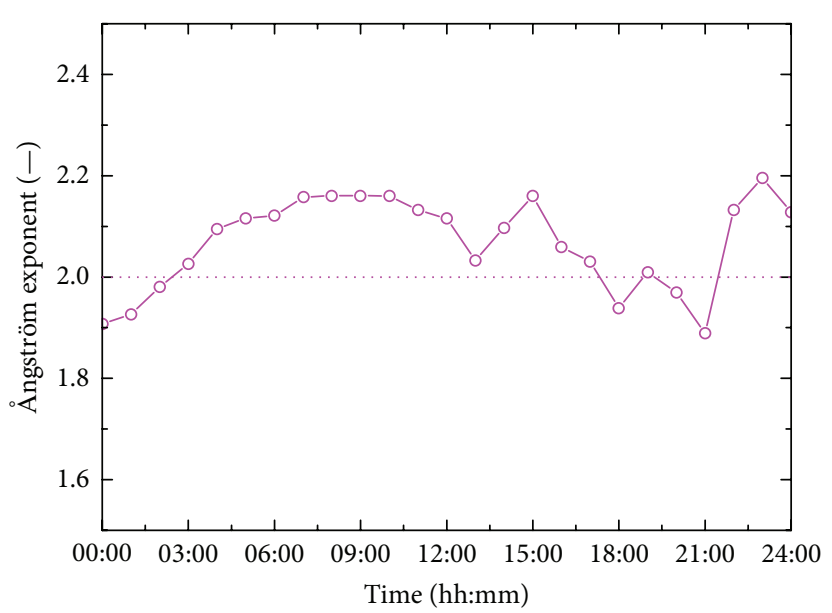

(c)

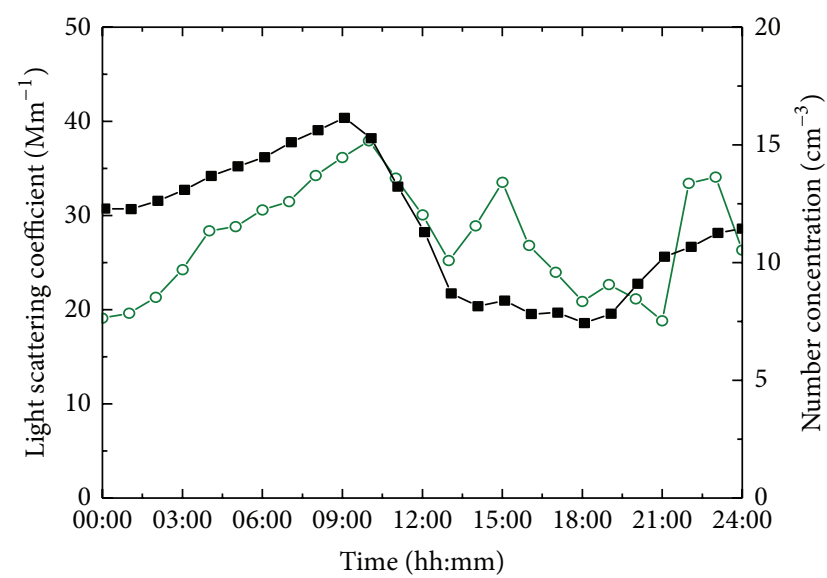

$\multimap$ Light scattering coefficient for $550 \mathrm{~nm}$

$\rightarrow$ Number concentration $\left(D_{\mathrm{pa}}>0.5 \mu \mathrm{m}\right)$

(b)

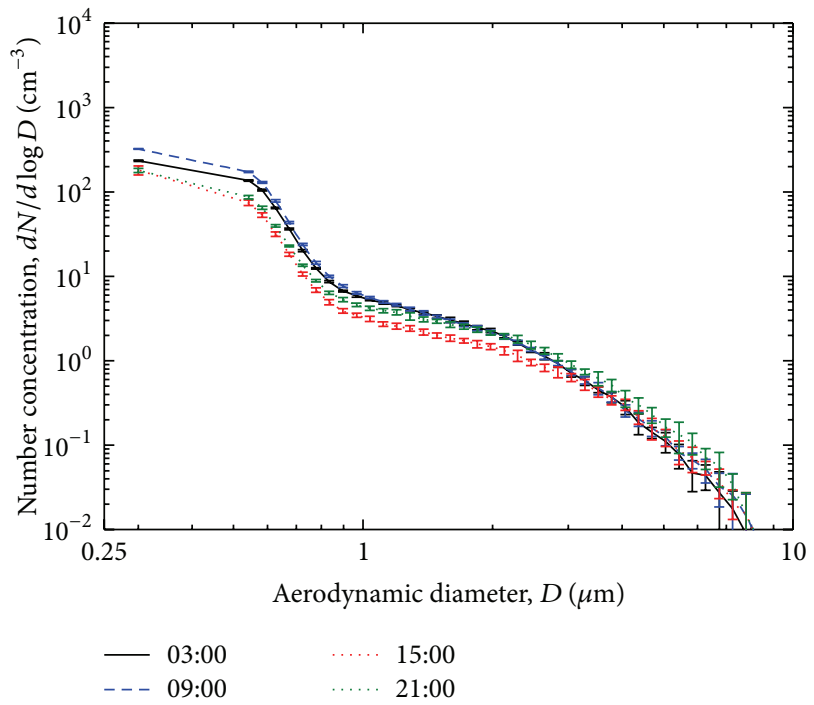

(d)

FIgURE 4: (a) Air parcel trajectory analysis from the National Oceanic and Atmospheric Administration (NOAA) Air Resources Laboratory (ARL) HYSPLIT model. For this analysis, the model was run backwards for 96 hours from 29th July 2012 at 12 UTC. Traces show the origin of air parcels at Vilnius at the $500 \mathrm{~m}$ (red), $1500 \mathrm{~m}$ (blue), and $2500 \mathrm{~m}$ (green) levels. (b) The variation of the measured and hourly averaged values of the light scattering coefficient at $550 \mathrm{~nm}$ and the particle number concentration. (c) The calculated Ångström exponent for 450 and $700 \mathrm{~nm}$ wavelength pair. (d) The particle size distributions.

intensive Saharan dust intrusion. The two-modal particle size distribution was observed with the mean particle diameters at 0.55 and $2 \mu \mathrm{m}$ (Figure 5(d)).

As in the case of the 3rd of July, observations have suggested that increase of the light scattering coefficient and the particle number concentration $\left(D_{\mathrm{pa}}>0.5 \mu \mathrm{m}\right)$ was not influenced by local sources as the daily variation of both parameters was not pronounced (7-12 p.m.) (Figure 6(b)).
The particle number concentration started to increase at 3 a.m. when the local traffic influence was negligible. The mixing of different types of air mass ("SW" and "N" sectors) arriving at 3 a.m. could lead to a regional mixed plume with modified properties. Figure 6(a) highlights air masses arriving over Vilnius on the 3rd of July 2012 at $1500 \mathrm{~m}$ altitude transported from Sahara dust plume extended across the Atlantic Ocean toward Great Britain. This makes one think 


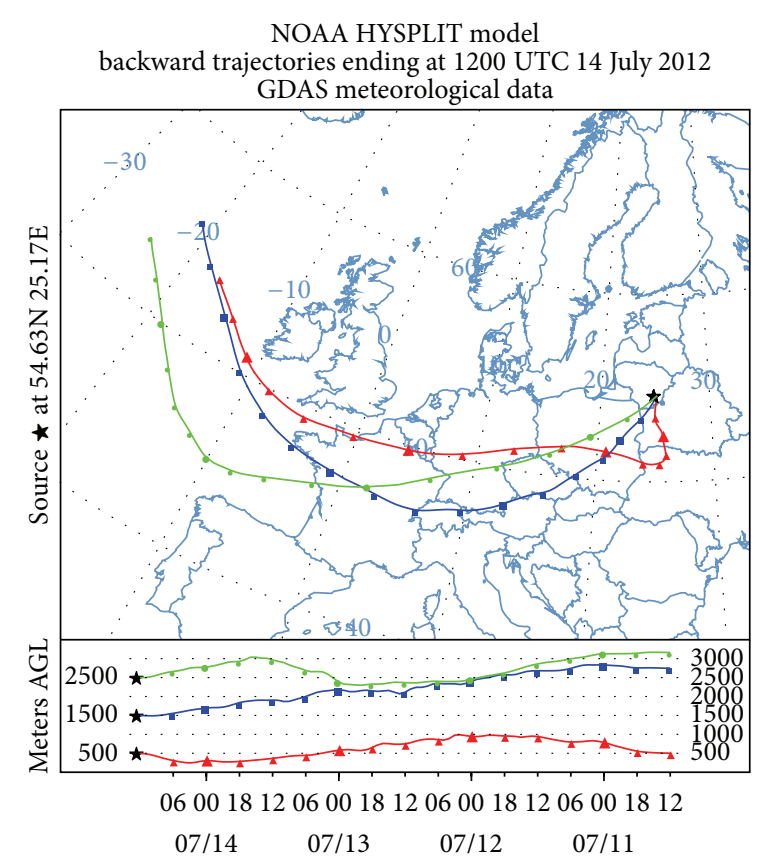

(a)

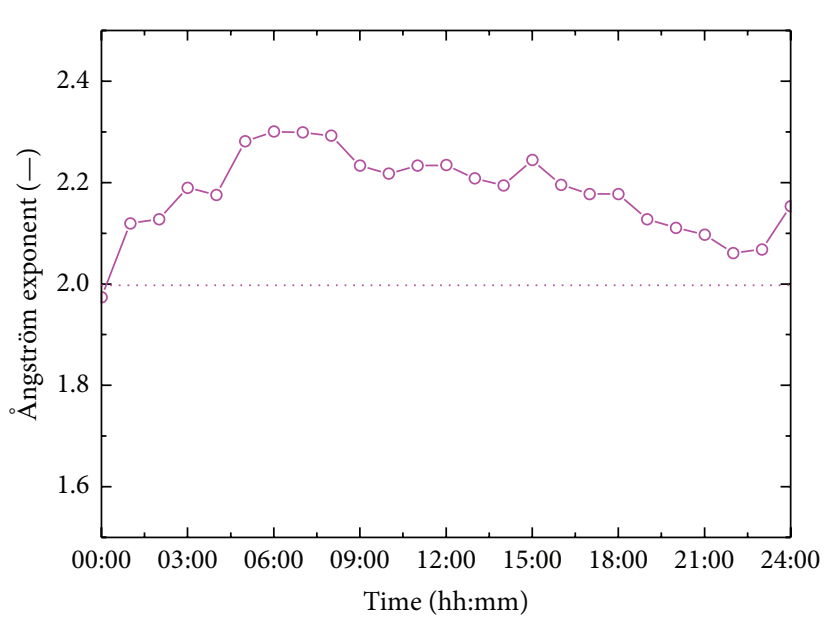

(c)

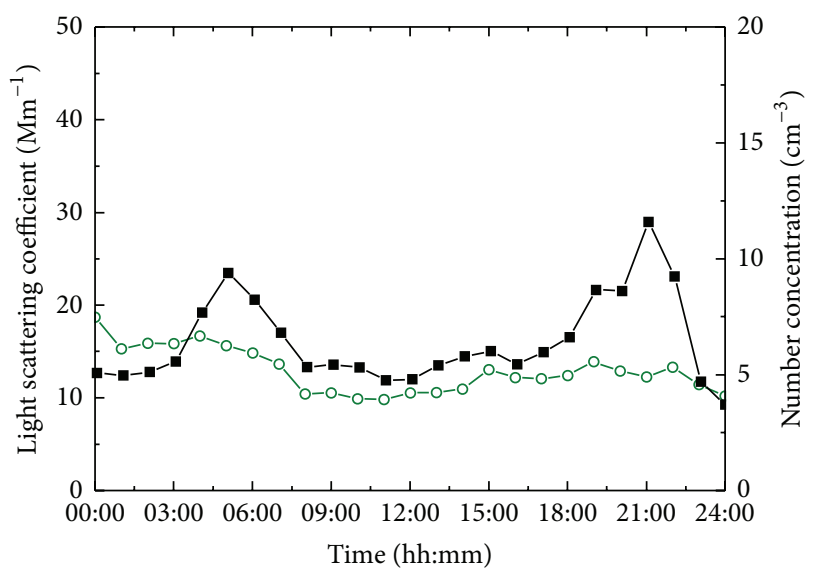

-0 Light scattering coefficient for $550 \mathrm{~nm}$

- Number concentration $\left(D_{\mathrm{pa}}>0.5 \mu \mathrm{m}\right)$

(b)

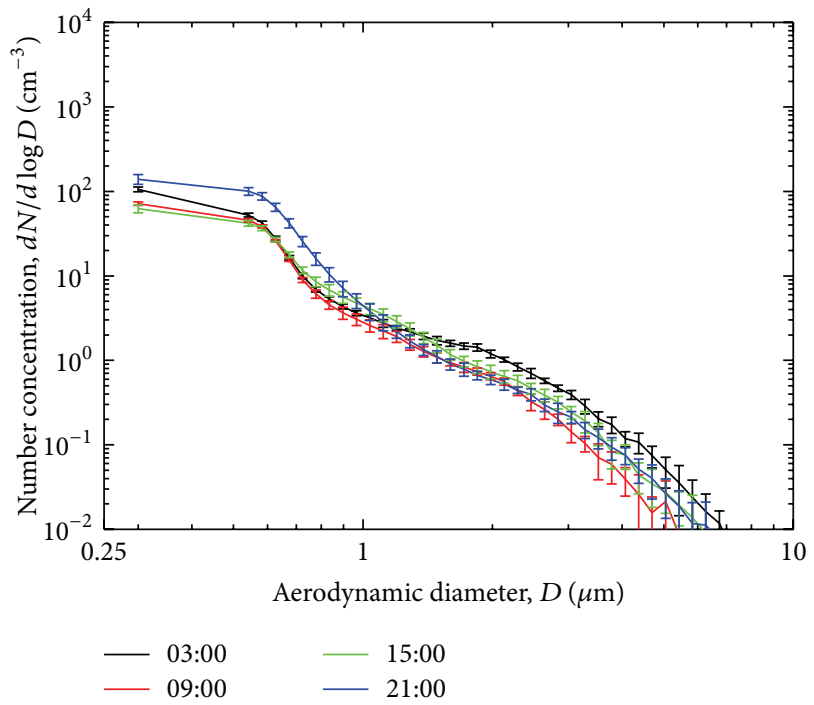

(d)

FIgure 5: (a) Air parcel trajectory analysis from the National Oceanic and Atmospheric Administration (NOAA) Air Resources Laboratory (ARL) HYSPLIT model. For this analysis, the model was run backwards for 96 hours from 14 July 2012 at 12 UTC. Traces show the origin of air parcels at Vilnius at the $500 \mathrm{~m}$ (red), $1500 \mathrm{~m}$ (blue), and $2500 \mathrm{~m}$ (green) levels. (b) The variation of the measured and hourly averaged values of the light scattering coefficient at $550 \mathrm{~nm}$ and the particle number concentration. (c) The calculated Ångström exponent for 450 and $700 \mathrm{~nm}$ wavelength pair. (d) The particle size distributions.

that loading the atmosphere with coarse aerosol particles during this period is mainly Saharan dust type. Thick dust which blew through the Sahara desert in late June 2012 (http://earthobservatory.nasa.gov/NaturalHazards/) extended over parts of Algeria, Mali, Mauritania, Morocco, and Atlantic Ocean. To validate this idea, we used CALIPSO and NAAPS satellite data (Figures 7-8).

A sudden increase in the aerosol number concentration $\left(118 \mathrm{~cm}^{-3}\right)$ and light scattering coefficient $\left(276 \mathrm{Mm}^{-1}\right)$ was observed on 3 July over Lithuania which can be attributed to the Sahara dust event in Europe as well as to some industrial activities in that region. At the same time, Ångström exponent decreased to 1.4. The massive export of dust from Sahara is observed starting 23rd June, while the dust plume spread over Western parts of Europe including Lithuania only on the 3rd of July. Lidar data measured on 23 June 2012 between 9:30 UTC and 18:30 UTC confirm the existence of an aerosol layer in the atmosphere above Vilnius between 4 and 


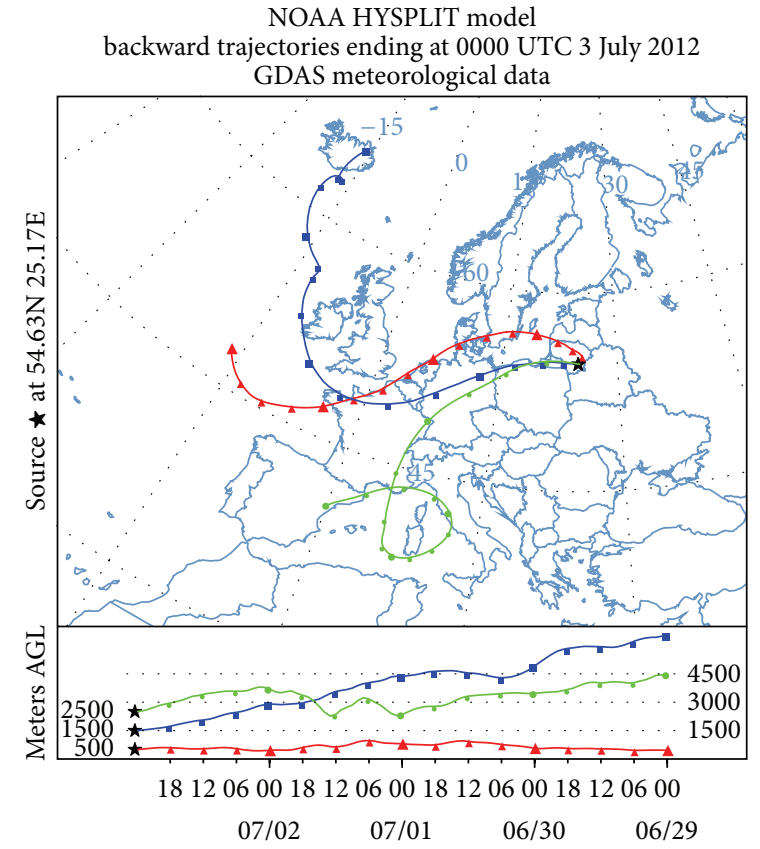

(a)

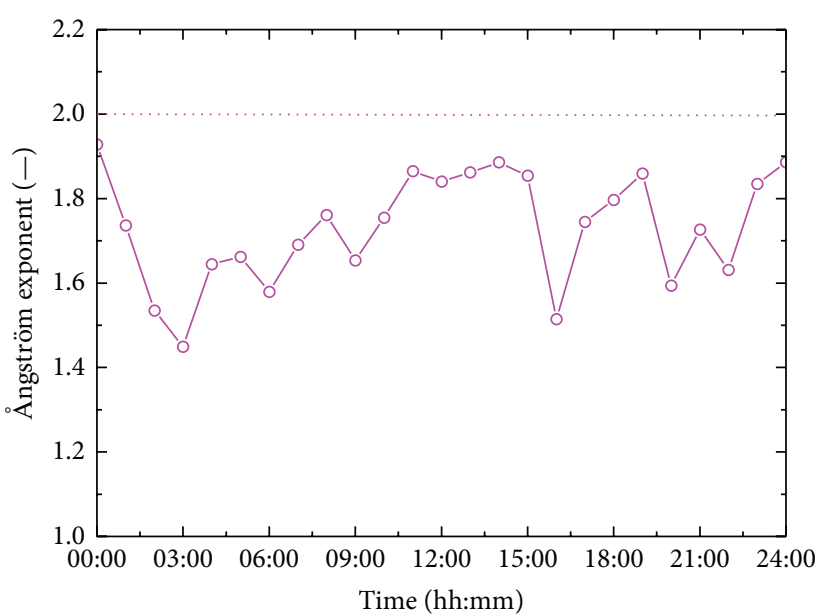

(c)

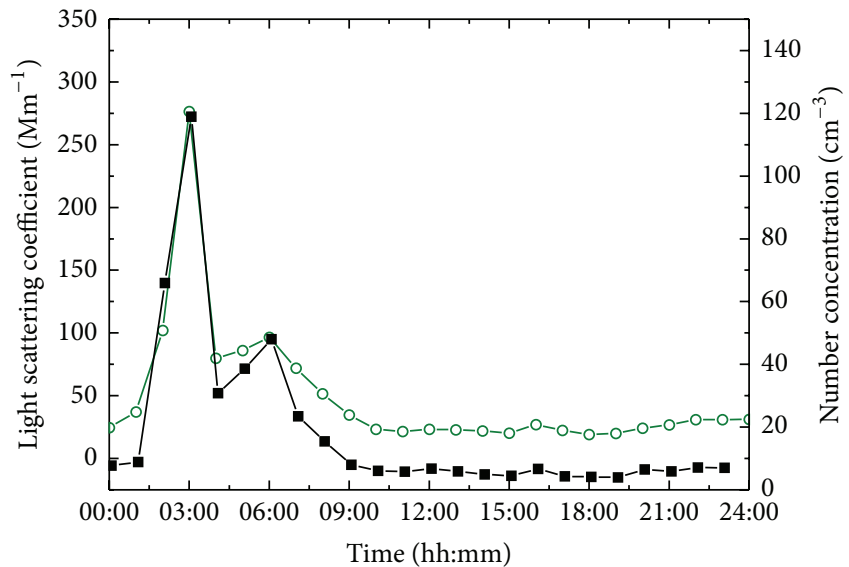

$\multimap$ Light scattering coefficient for $550 \mathrm{~nm}$

$\rightarrow$ Number concentration $\left(D_{\mathrm{pa}}>0.5 \mu \mathrm{m}\right)$

(b)

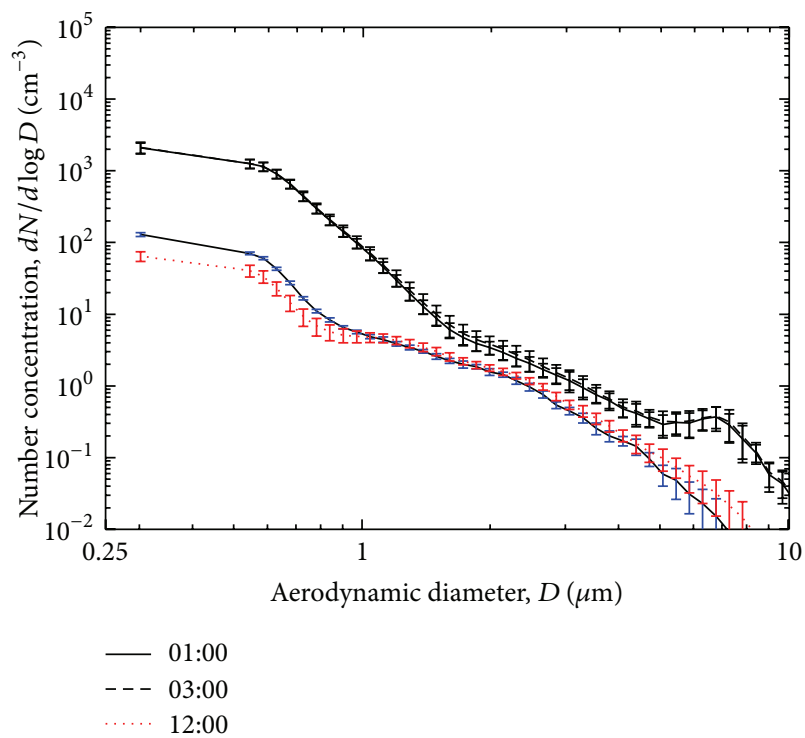

(d)

FIgURE 6: (a) Air parcel trajectory analysis from the National Oceanic and Atmospheric Administration (NOAA) Air Resources Laboratory (ARL) HYSPLIT model. For this analysis, the model was run backwards for 96 hours from 3 July 2012 at 00 UTC. Traces show the origin of air parcels at Vilnius at the $500 \mathrm{~m}$ (red), $1500 \mathrm{~m}$ (blue), and $2500 \mathrm{~m}$ (green) levels. (b) The variation of the measured and hourly averaged values of the light scattering coefficient at $550 \mathrm{~nm}$ and the particle number concentration. (c) The Ångström exponent for 450 and $700 \mathrm{~nm}$ wavelength pair. (d) The particle size distributions.

$5 \mathrm{~km}$, which descends in time below $3 \mathrm{~km}$ after 17:00 UTC. Grey shades indicate a change in aerosol type. Black region is due to laser stop for half an hour (Figure 7). The CALIPSO classification scheme identified two types of aerosol layers: pure dust (orange) and polluted dust (brown). In this study, aerosol (low confidence) could be defined as a mixture of pure dust and anthropogenic pollution formed during air mass transport.

The particle size distribution showed two modes in the spectra at 0.6 and $6.70 \mu \mathrm{m}$. Comparing the particle size distribution at 3 a.m. and at 9 a.m., it is seen that the second mode disappeared and the particle number concentration 


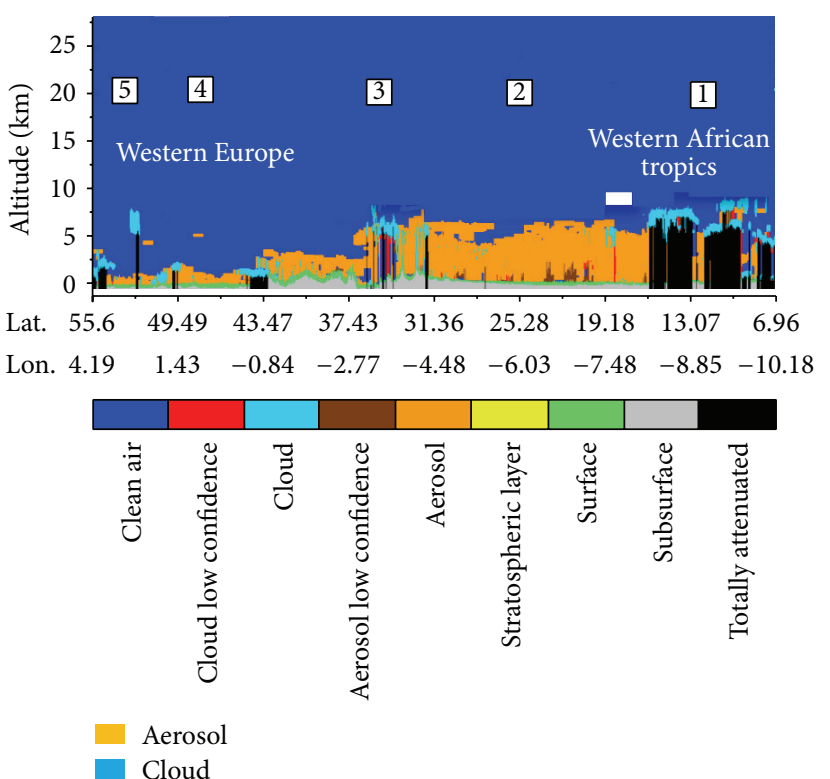

(a)
CALIPSO Lidar signal (23 June 2012) (begin: 02:15:46.0, end: 02:29:14.7 night time)

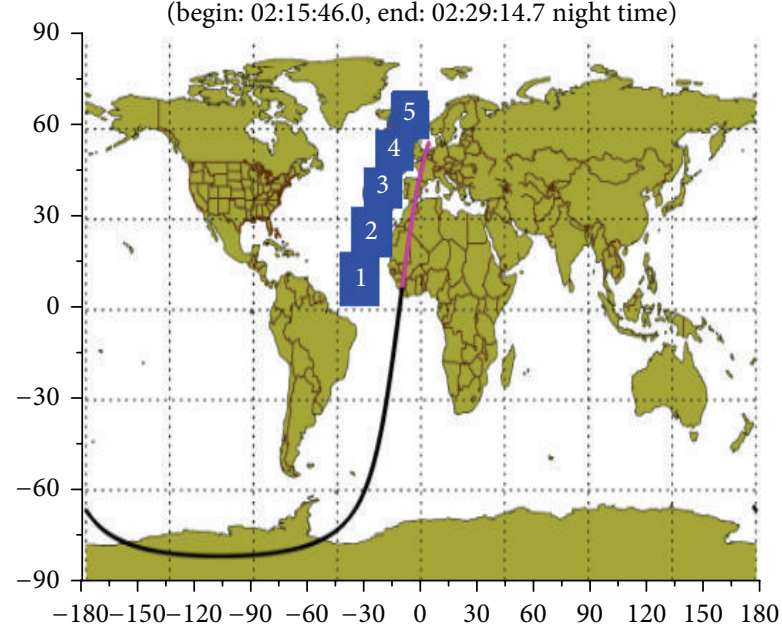

(b)

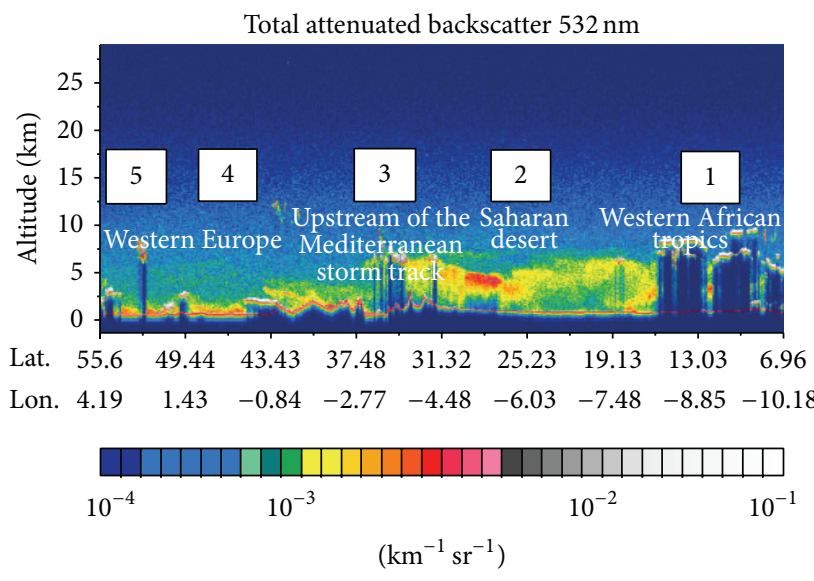

(c)

FIgURE 7: (a) Vertical feature mask shows the CALIPSO aerosol subtypes. (b-c) Total attenuated backscatter at $532 \mathrm{~nm}$ along with the orbit track (b) $\left(\mathrm{km}^{-1} \mathrm{sr}^{-1}\right)$; the colour bars for attenuated backscatter show the colors assigned to ranges of attenuated backscatter, $\mathrm{km}^{-1} \mathrm{sr}^{-1}$; the vertical axes are annotated to indicate altitude in kilometers; the horizontal axes are annotated with latitude in kilometres (deg) and longitude (deg).

$\left(D_{\mathrm{pa}}>0.5 \mu \mathrm{m}\right)$ and the light scattering coefficient decreased (Figure 6(d)).

AOD based on the satellite measurements shows that the penetration of the Sahara dust to the Baltic region (Figure 8) was observed from the 1st to the 8th of July 2012.

From the Atlantic Ocean, the dust formed the arc bents eastward in the direction of the Mediterranean Sea. Thus, the dust has spread over the Atlantic and turned to the North getting the UK islands. Another part of the dust crossed Europe directly from the Mediterranean Sea region through Italy, Germany, and Poland. Arriving air masses were mixed with the air from other regions. As a result, the aerosol was diluted with the clean air decreasing the high values of the particle number concentration and light scattering coefficients. However, the event on the 3rd of July clearly illustrates increasing of the particle number concentration $\left(D_{\mathrm{pa}}>0.5 \mu \mathrm{m}\right)$ correlating with the rapid light scattering coefficient increasing. Also, the appearance of the second particle mode with the peak at $7 \mu \mathrm{m}$ of the particle size distribution was observed. That presents the appearance of the dust particles in the local ambient air at the time when the local pollution sources have a minimal influence. The Sahara dust intrusions are very frequent in South Europe. In Spain, Italy, and Greece, the number of days when carrying of a dust from Northern Africa is observed makes up 20-30\%. In the region of Belarus, such episodes make up 5-10\% [55]. 


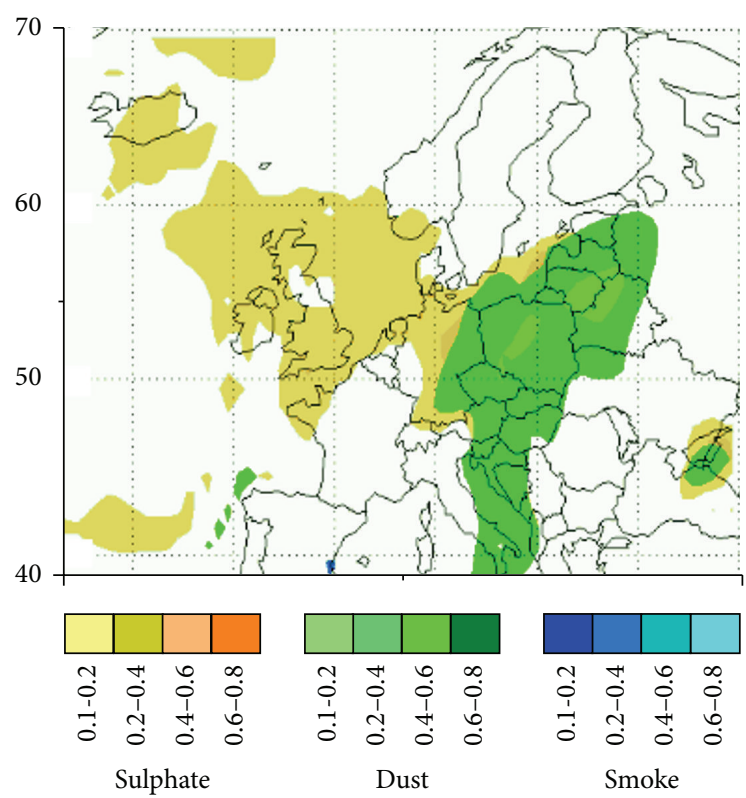

FIGURE 8: The dust distribution over Europe on the 3rd of July by satellite measurements and NAAPS distribution model.

The high dust particle number concentrations are observed close to the Mediterranean Sea region and they decreased over West and Central Europe coming highly diluted in the East region. The vertical profile of the Sahara dust over South Europe is distributed mainly at heights of $1.5-8 \mathrm{~km}$ [56]. With an increase in the distance from Sahara storm location, the average height of the dust layer increased. For example, in the region of Belarus, the dust layer concentrates at a height of 3-8 km [56]. Thus, the air masses from the Sahara region transported the sand dust over Lithuania in the middle free troposphere.

\section{Conclusions}

The ground based measurements of the light scattering coefficients for 450,550 , and $700 \mathrm{~nm}$, the particle number concentration $\left(D_{\mathrm{pa}}>0.5 \mu \mathrm{m}\right)$, and the particle size distribution from 0.5 to $12 \mu \mathrm{m}$ in conjunction with satellite measurements were investigated during July 2012 in urban environment. The investigation of the air mass backward trajectories and the regional AOD distribution over Europe allowed determining the far located air pollution sources and their effect on the typical local aerosol physical and optical properties. It was determined that the cleanest air masses arrived from the Atlantic Ocean and Scandinavia. The trends observed in the AOD and the Angström exponent were consistent with the dependences found in the size distributions. The major source of small particles occurred when the air mass crossed the industrialized areas of Europe or was sourced locally, pointing to the influence of anthropogenic particles related to both urban and industrial pollution. Inversely, the major contribution of coarse particles occurred when the dominant air masses were transported from Sahara dust plume extended across the Atlantic Ocean toward Great Britain. As a result, the light scattering coefficient suddenly increased to $276 \mathrm{Mm}^{-1}$ and the particle number concentration increased up to $118 \mathrm{~cm}^{-3}$, while the Ångström exponent decreased to 1.4. The measurements of the optical and physical particle properties determined two dominating types of the aerosol particles dividing them into two sectors "the high scattering sector" and "the low scattering sector" described by three parameters $\alpha_{H}=63.6^{\circ}, \alpha_{L}=24.1^{\circ}$, and $\beta=39.5^{\circ}$. It was evaluated that aerosol properties depended on the air mass properties. For example, "the high scattering sector" consists of the aerosol particles from the Mediterranean Sea region, while "low scattering sector" is formed by particles from the Atlantic Ocean.

The optical property characterization of the local aerosol particles cannot be done accurately based only on the satellite measurements of the AOD. The most detailed characterization can be obtained referring to the ground based measurements of the light scattering coefficient, the particle number concentration, and the particle size distribution.

\section{Conflict of Interests}

The authors declare that they have no competing interests as defined by this journal or other interests that might be perceived to influence the results and discussion reported in this paper.

\section{Acknowledgment}

This research was partially supported by FP7 TRANSPHORM.

\section{References}

[1] C. A. Pope, D. W. Dockery, and J. Schwartz, "Review of epidemiological evidence of health effects of particulate air pollution," Inhalation Toxicology, vol. 7, no. 1, pp. 1-18, 1995.

[2] H. L. Horvath, A. Arboledas, F. J. Olmo et al., "Optical characteristics of the aerosol in Spain and Austria and its effect on radiative forcing," Journal of Geophysical Research, vol. 107, no. 19, p. 4386, 2002.

[3] D. Meloni, A. di Sarra, T. di Iorio, and G. Fiocco, "Influence of the vertical profile of Saharan dust on the visible direct radiative forcing," Journal of Quantitative Spectroscopy and Radiative Transfer, vol. 93, no. 4, pp. 397-413, 2005.

[4] M. Santese, F. De Tomasi, and M. R. Perrone, "Advection patterns and aerosol optical and microphysical properties by AERONET over south-east Italy in the central Mediterranean," Atmospheric Chemistry and Physics, vol. 8, no. 7, pp. 1881-1896, 2008.

[5] M. O. Andreae and P. J. Crutzen, "Atmospheric aerosols: biogeochemical sources and role in atmospheric chemistry," Science, vol. 276, no. 5315, pp. 1052-1058, 1997.

[6] Intergovernmental Panel on Climate Change (IPCC), The Scientific Basis. Contribution of Working Group I to the Third Assessment Report of the Intergovernmental Panel on Climate Change, Cambridge University Press, New York, NY, USA, 2001.

[7] L. McInnes, M. Bergin, J. Ogren, and S. Schwartz, "Apportionment of light scattering and hygroscopic growth to aerosol composition," Geophysical Research Letters, vol. 25, no. 4, pp. 513516, 1998. 
[8] E. Mészáros, A. Molnár, and J. Ogren, "Scattering and absorption coefficients vs. chemical composition of fine atmospheric aerosol particles under regional conditions in Hungary," Journal of Aerosol Science, vol. 29, no. 10, pp. 1171-1178, 1998.

[9] L. W. Richards, S. H. Alcorn, C. McDade et al., "Optical properties of the San Joaquin Valley aerosol collected during the 1995 integrated monitoring study," Atmospheric Environment, vol. 33, no. 29, pp. 4787-4795, 1999.

[10] K. Chamaillard, C. Kleefeld, S. G. Jennings, D. Ceburnis, and C. D. O'Dowd, "Light scattering properties of sea-salt aerosol particles inferred from modeling studies and ground-based measurements," Journal of Quantitative Spectroscopy and Radiative Transfer, vol. 101, no. 3, pp. 498-511, 2006.

[11] C. Kleefeld, C. D. O’Dowd, S. O’Reilly et al., "Relative contribution of submicron and supermicron particles to aerosol light scattering in the marine boundary layer," Journal of Geophysical Research, vol. 107, no. 19, 2002.

[12] H. Lyamani, F. J. Olmo, and L. Alados-Arboledas, "Light scattering and absorption properties of aerosol particles in the urban environment of Granada, Spain," Atmospheric Environment, vol. 42, no. 11, pp. 2630-2642, 2008.

[13] M. Z. Jacobson, "A physically-based treatment of elemental carbon optics: implications for global direct forcing of aerosols," Geophysical Research Letters, vol. 27, no. 2, pp. 217-220, 2000.

[14] P. J. Sheridan, E. Andrews, J. A. Ogren, J. L. Tackett, and D. M. Winker, "Vertical profiles of aerosol optical properties over central Illinois and comparison with surface and satellite measurements," Atmospheric Chemistry and Physics, vol. 12, no. 23, pp. 11695-11721, 2012.

[15] J. E. Penner, M. Andreae, H. Annegarn et al., "Aerosols, their direct and indirect effects," in Climate Change 2001: The Scientific Basis, Contribution of Working Group I to the Third Assessment Report of the Intergovernmental Panel on Climate Change, J. T. Houghton, Y. Ding, D. J. Griggs et al., Eds., pp. 289-348, Cambridge University Press, Cambridge, UK, 2001.

[16] H. Liao and J. H. Seinfeld, "Global impacts of gas-phase chemistry-aerosol interactions on direct radiative forcing by anthropogenic aerosols and ozone," Journal of Geophysical Research D: Atmospheres, vol. 110, no. 18, Article ID D18208, 2005.

[17] B. Zhuang, Q. Liu, T. Wang et al., "Investigation on semi-direct and indirect climate effects of fossil fuel black carbon aerosol over China," Theoretical and Applied Climatology, vol. 114, no. 3-4, pp. 651-672, 2013.

[18] N. Bellouin, O. Boucher, D. Tanré, and O. Dubovik, "Aerosol absorption over the clear-sky oceans deduced from POLDER-1 and AERONET observations," Geophysical Research Letters, vol. 30, no. 14, p. 1748, 2003.

[19] J. Zhang, S. A. Christopher, L. A. Remer, and Y. J. Kaufman, "Shortwave aerosol radiative forcing over cloud-free oceans from Terra: 2. Seasonal and global distributions," Journal of Geophysical Research D: Atmospheres, vol. 110, no. 10, pp. 1-10, 2005.

[20] S. A. Christopher, J. Zhang, Y. J. Kaufman, and L. A. Remer, "Satellite-based assessment of top of atmosphere anthropogenic aerosol radiative forcing over cloud-free oceans," Geophysical Research Letters, vol. 33, no. 15, Article ID L15816, 2006.

[21] A. K. Prasad, H. El-Askary, and M. Kafatos, "Implications of high altitude desert dust transport from Western Sahara to Nile Delta during biomass burning season," Environmental Pollution, vol. 158, no. 11, pp. 3385-3391, 2010.
[22] R. Gautam, Z. Liu, R. P. Singh, and N. C. Hsu, "Two contrasting dust-dominant periods over India observed from MODIS and CALIPSO data," Geophysical Research Letters, vol. 36, no. 6, Article ID L06813, 2009.

[23] M. Kulmala, A. Asmi, H. K. Lappalainen et al., "Introduction: European Integrated Project on Aerosol Cloud Climate and Air Quality interactions (EUCAARI) integrating aerosol research from nano to global scales," Atmospheric Chemistry and Physics, vol. 9, no. 23, pp. 2825-2841, 2009.

[24] R. C. Levy, L. A. Remer, R. G. Kleidman et al., "Global evaluation of the Collection 5 MODIS dark-target aerosol products over land," Atmospheric Chemistry and Physics, vol. 10, no. 21, pp. 10399-10420, 2010.

[25] V. V. Salomonson, W. L. Barnes, P. W. Maymon, H. E. Montgomery, and H. Ostrow, "MODIS: advanced facility instrument for studies of the earth as a system," IEEE Transactions on Geoscience and Remote Sensing, vol. 27, no. 2, pp. 145-153, 1992.

[26] IPCC, Climate Change 2014: Impacts, Adaptation, and Vulnerability, Part A: Global and Sectoral Aspects, Contribution of Working Group II to the Fifth Assessment Report of the Intergovernmental Panel on Climate Change, edited by C. B. Field, V. R. Barros, D. J. Dokken etal, Cambridge University Press, New York, NY, USA, 2014.

[27] J. Al-Saadi, J. Szykman, R. B. Pierce et al., "Improving national air quality forecasts with satellite aerosol observations," Bulletin of the American Meteorological Society, vol. 86, no. 9, pp. 12491261, 2005.

[28] A. van Donkelaar, R. V. Martin, M. Brauer et al., "Global estimates of ambient fine particulate matter concentrations from satellite-based aerosol optical depth: development and application," Environmental Health Perspectives, vol. 118, no. 6, pp. 847$855,2010$.

[29] J. Wang and S. A. Christopher, "Intercomparison between satellite-derived aerosol optical thickness and PM2.5 mass: implications for air quality studies," Geophysical Research Letters, vol. 30, no. 21, article 2095, 2003.

[30] A. Nemuc, L. Belegante, and R. Radulescu, "One year of sunphotometer measurements in Romania," Romanian Journal of Physics, vol. 56, no. 3-4, pp. 550-562, 2011.

[31] T. L. Anderson, D. S. Covert, S. F. Marshall et al., "Performance characteristics of a high-sensitivity, three-wavelength, total scatter/backscatter nephelometer," Journal of Atmospheric and Oceanic Technology, vol. 13, no. 5, pp. 967-986, 1996.

[32] T. L. Anderson and J. A. Ogren, "Determining aerosol radiative properties using the TSI 3563 integrating nephelometer," Aerosol Science and Technology, vol. 29, no. 1, pp. 57-69, 1998.

[33] C. Kleefeld, C. D. O’Dowd, S. O’Reilly et al., "Relative contribution of submicron and supermicron particles to aerosol light scattering in the marine boundary layer," Journal of Geophysical Research D: Atmospheres, vol. 107, no. 19, article 8103, 2002.

[34] K. Willeke and P. A. Baron, Eds., Aerosol Measurement: Principles, Techniques, and Applications, Van Nostrand Reinhold, New York, NY, USA, 1993.

[35] B. B. Chen, L. G. Sverdlik, and S. A. Imashev, "Dynamics of accumulation mode particles at transboundary aerosol transport," Herald of the KRSU Series: Physics, vol. 9, no. 11, pp. 73-85, 2009.

[36] R. R. Draxler and G. D. Rolph, HYSPLIT (Hybrid Single-Particle Lagrangian Integrated Trajectory) Model Access via NOAA ARL READY Website, NOAA Air Resources Laboratory, Silver Spring, Md, USA, 2015, http://ready.arl.noaa.gov/HYSPLIT .php. 
[37] T. F. Hogan and T. E. Rosmond, "The description of the Navy Operational Global Atmospheric Prediction System's spectral forecast model," Monthly Weather Review, vol. 119, no. 8, pp. 1786-1815, 1991.

[38] T. F. Hogan and L. R. Brody, "Sensitivity studies of the Navy's global forecast model parameterizations and evaluation of improvements to NOGAPS," Monthly Weather Review, vol. 121, no. 8, pp. 2373-2395, 1993.

[39] Y. J. Kaufman, D. Tanré, L. A. Remer, E. F. Vermote, A. Chu, and B. N. Holben, "Operational remote sensing of tropospheric aerosol over land from EOS moderate resolution imaging spectroradiometer," Journal of Geophysical Research D: Atmospheres, vol. 102, no. 14, pp. 17051-17067, 1997.

[40] L. Remer, R. Kleidman, R. Levy et al., "Global aerosol climatology from the MODIS satellite sensors," Journal of Geophysical Research: Atmospheres, vol. 113, no. D14, Article ID D14S07, 2008.

[41] R. C. Levy, L. A. Remer, S. Mattoo, E. F. Vermote, and Y. J. Kaufman, "Second-generation operational algorithm: retrieval of aerosol properties over land from inversion of Moderate Resolution Imaging Spectroradiometer spectral reflectance," Journal of Geophysical Research D: Atmospheres, vol. 112, no. 13, Article ID D13211, 2007.

[42] R. Levy, L. Remer, D. Tanŕe, S. Mattoo, Y. Kaufman, and D. Tanríe, "Algorithm for remote sensing of tropospheric aerosol over dark targets from MODIS: collections 005 and 051: revision 2," MODIS Algorithm Theoretical Basis Document, 2009.

[43] D. A. Chu, Y. J. Kaufman, C. Ichoku, L. A. Remer, D. Tanré, and B. N. Holben, "Validation of MODIS aerosol optical depth retrieval over land," Geophysical Research Letters, vol. 29, no. 12, 2002.

[44] C. Ichoku, L. A. Remer, Y. J. Kaufman et al., "MODIS observation of aerosols and estimation of aerosol radiative forcing over southern Africa during SAFARI 2000," Journal of Geophysical Research D: Atmospheres, vol. 108, no. 13, article 8499, 2003.

[45] P. B. Russell, R. W. Bergstrom, Y. Shinozuka et al., "Absorption Ångström Exponent in AERONET and related data as an indicator of aerosol composition," Atmospheric Chemistry and Physics, vol. 10, no. 3, pp. 1155-1169, 2010.

[46] M. Vrekoussis, E. Liakakou, M. Koçak et al., "Seasonal variability of optical properties of aerosols in the Eastern Mediterranean," Atmospheric Environment, vol. 39, no. 37, pp. 70837094, 2005

[47] A. Aculinin, V. Smicov, B. Holben et al., "Variability of total column ozone content measured at the Kishinev site, Moldova," Moldavian Journal of the Physical Sciences, vol. 5, no. 2, pp. 240248, 2006.

[48] C. Chou, O. Stetzer, E. Weingartner, Z. Jurányi, Z. A. Kanji, and U. Lohmann, "Ice nuclei properties within a Saharan dust event at the Jungfraujoch in the Swiss Alps," Atmospheric Chemistry and Physics, vol. 11, no. 10, pp. 4725-4738, 2011.

[49] C. D. O’Dowd, M. C. Facchini, F. Cavalli et al., "Biogenically driven organic contribution to marine aerosol," Nature, vol. 431, no. 7009, pp. 676-680, 2004.

[50] S. Bauer, E. Bierwirth, M. Esselborn et al., "Airborne spectral radiation measurements to derive solar radiative forcing of Saharan dust mixed with biomass burning smoke particles," Tellus, Series B: Chemical and Physical Meteorology, vol. 63, no. 4, pp. 742-750, 2011.
[51] K. Kandler, N. Benker, U. Bundke et al., "Chemical composition and complex refractive index of Saharan Mineral Dust at Izaña, Tenerife (Spain) derived by electron microscopy," Atmospheric Environment, vol. 41, no. 37, pp. 8058-8074, 2007.

[52] G. Gangoiti, L. Alonso, M. Navazo, J. A. García, and M. M. Millán, "North African soil dust and European pollution transport to America during the warm season: hidden links shown by a passive tracer simulation," Journal of Geophysical Research D: Atmospheres, vol. 111, no. 10, Article ID D10109, 2006.

[53] E. Gerasopoulos, M. O. Andreae, C. S. Zerefos et al., "Climatological aspects of aerosol optical properties in Northern Greece," Atmospheric Chemistry and Physics, vol. 3, no. 6, pp. 2025-2041, 2003.

[54] M. R. Perrone and A. Bergamo, "Direct radiative forcing during Sahara dust intrusions at a site in the Central Mediterranean: anthropogenic particle contribution," Atmospheric Research, vol. 101, no. 3, pp. 783-798, 2011.

[55] Report on the Research Work, Assessment Large-Scale and Cross-Border Transfer Pollution in the Atmosphere with Use of Systems Remote Sensing and Data Global and Regional Measuring Networks, Institute of Physics of Stepanov, Minsk, Belarus, 2010, http://scat.bas-net.by/ lidarteam/Transboundary\%20transport-ru/Report-2008.pdf.

[56] A. Papayannis, V. Amiridis, L. Mona et al., "Systematic lidar observations of Saharan dust over Europe in the frame of EARLINET (2000-2002)," Journal of Geophysical Research, vol. 113, Article ID D10204, 2008. 

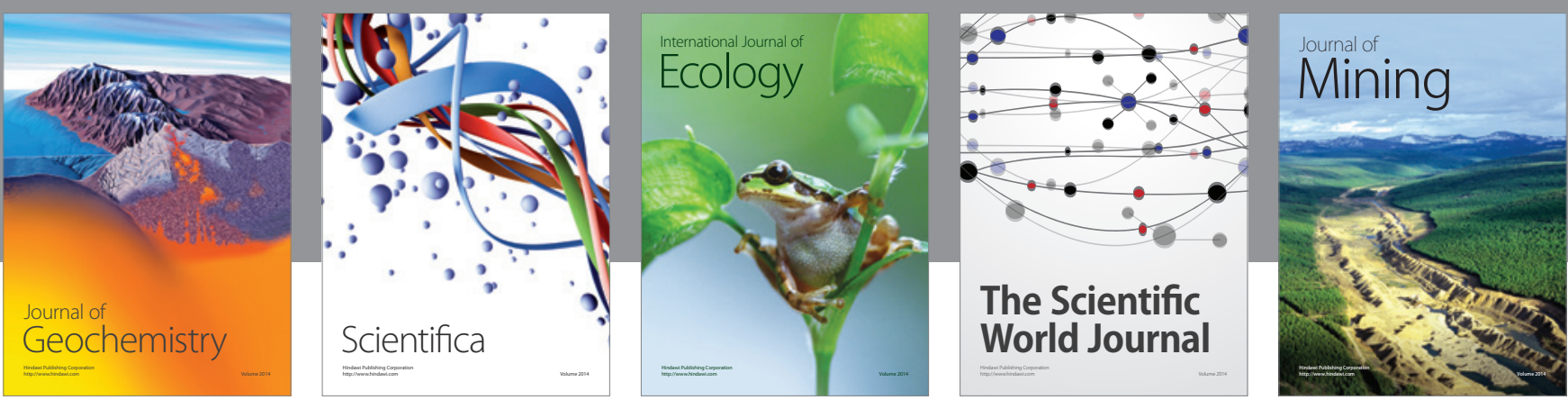

The Scientific World Journal
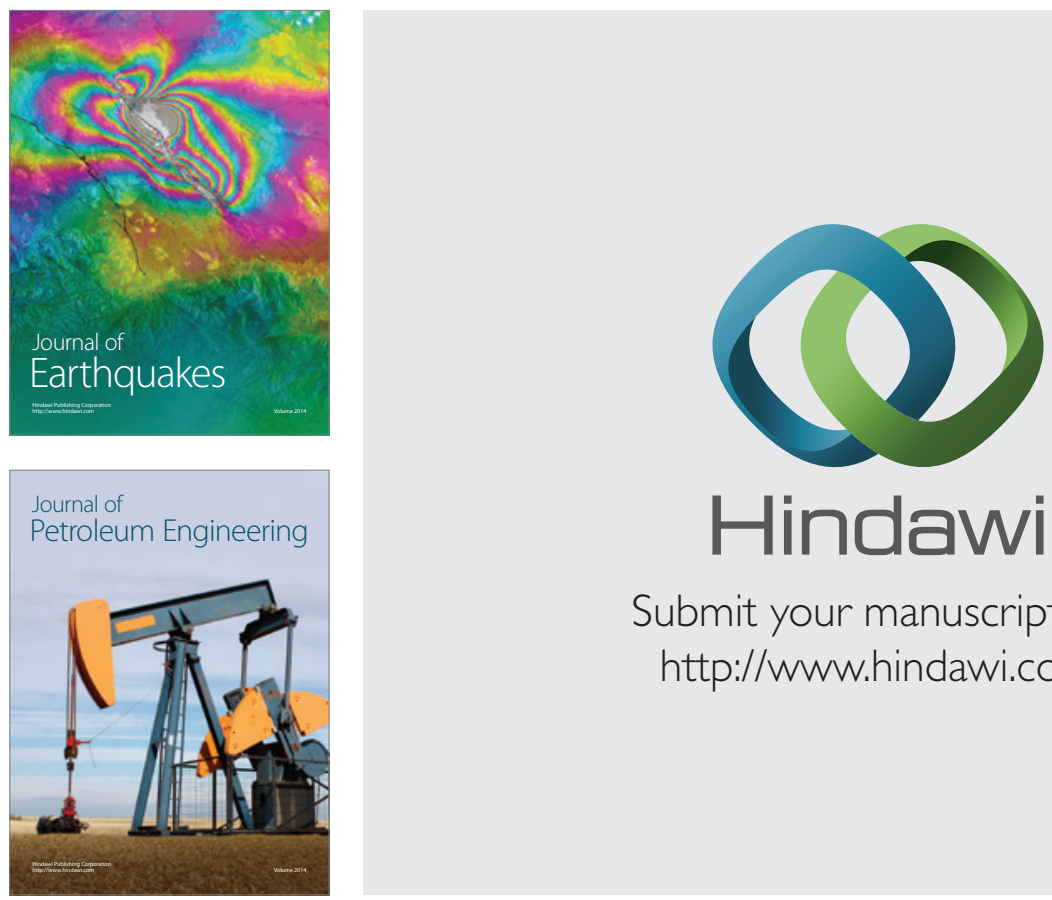

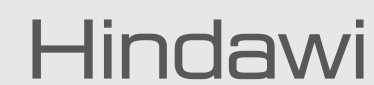

Submit your manuscripts at

http://www.hindawi.com
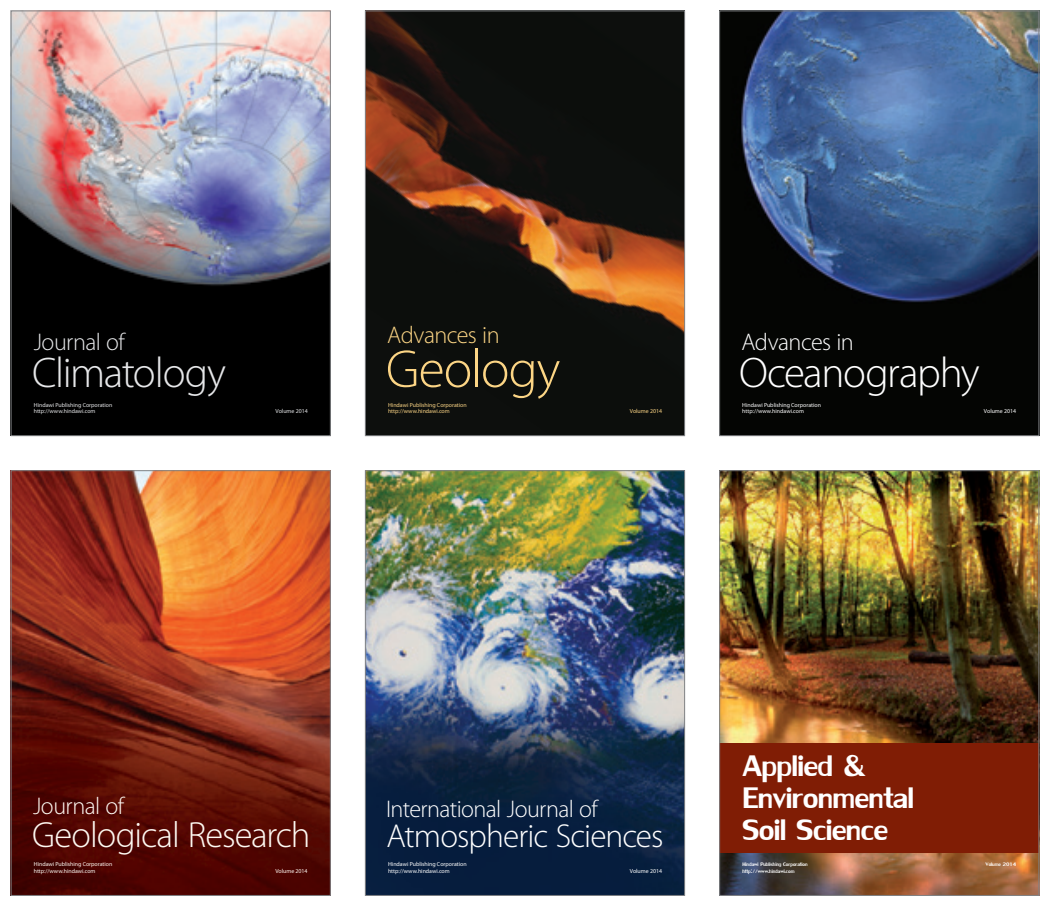
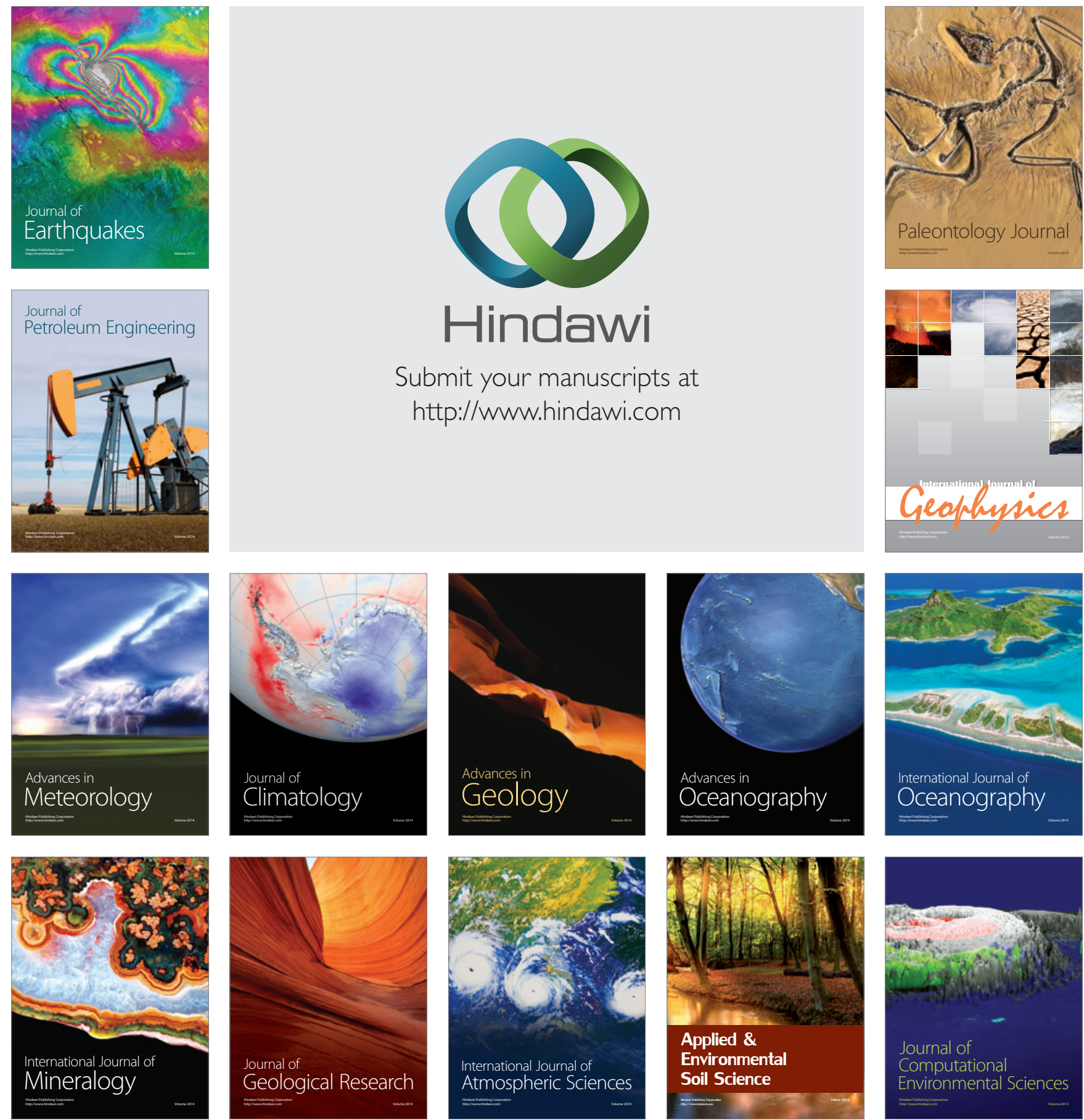